\title{
Variations of the Lost Hero: Blood on the Ice in Christoph Ransmayr's Schrecken des Eises und der Finsternis
}

\section{Lynne Cook}

Christoph Ransmayr's Schrecken des Eises und der Finsternis spans events in the last century of the thousand years of Austrian culture available to be reflected upon during the course of this year. In the novel, during the height and might of the Empire, the explorers Weyprecht and Payer lead the 1872 Austro-Hungarian expedition to the North Pole. In the parallel narrative strand a hundred or so years later, in a less auspicious age, the solitary Josef Mazzini boards a Scandinavian Airlines flight in Vienna and heads north too, intending to follow in Weyprecht and Payer's footsteps.

The text purportedly owes its existence to the disappearance of Josef Mazzini in the Arctic winter of 1981. The Ich-Erzähler, a member of Mazzini's circle in Vienna, constructs an interpretation of an interpretation: his response to Mazzini's response, to the 1872-4 North Pole expedition of Weyprecht and Payer, because "...wenn einer verloren geht, ohne einen greifbaren Rest zu hinterlassen, etwas, das man verbrennen, versenken oder verscharren kann, dann muß er wohl erst in den Geschichten, die man nach seinem Verschwinden über ihn zu erzählen beginnt, allmählich und endgültig aus der Welt geschafft werden" (11). ${ }^{1}$ Using the lost Mazzini's journals and the original expedition papers acquired from historical archives, the Ich-Erzähler assumes the authorship of a journey of which he has no authentic experience.

Central to the journeys, both "innere und äußere" of Mazzini, and Weyprecht and Payer is the idea of the lost hero. In my reading of the text I use the following definitions of 'hero'; I examine the representation of Mazzini, Weyprecht and Payer as principal male characters in each of the narrative strands of the text, and also examine the extent to which each character fulfils the definition of a hero as a man "distinguished by

${ }^{1}$ Ransmayr, Christoph: Schrecken des Eises und der Finsternis, Frankfurt a. M. 1987. 
exceptional courage, nobility and fortitude, a man idealised for possessing superior qualities."

The concept of the superior individual as Subject is one which has been increasingly eroded in importance, replaced by the doubting hero in literary modernity and disappearing altogether in the displaced hero of postmodern criticism. I argue that this can be seen in the several variations of the 'lost hero' in the two narrative strands of Ransmayr's novel. Thematically there is a questioning of the heroic role, which results in a recognition, in the experience of Weyprecht and Payer, of the transience of human fame and the devaluation of achievement. The hero does not endure. Also, the loss of the heroic act and the heroic actor is related to a perceived loss of authenticity of experience. This is critically reflected upon in the preface and illustrated in the anti-heroic experiences of the twentieth century traveller, Mazzini. In terms of narrative strategy, the hero is also lost due to his displacement as Subject. The Ich-Erzähler mediates the texts within his text and eventually appropriates Mazzini's place. He writes, "Es war die beschämende, lächerliche Entdeckung, daß ich gewissermaßen Mazzinis Platz eingenommen hatte. Ich tat ja seine Arbeit und bewegte mich in seinen Phantasien (25).

These variations of the concept of the lost hero; associated questions of suffering, transience, the loss of authenticity and displacement are illustrated on several levels by the image of blood on the ice. The blood on the ice can be the literal reality of man's existence and actions on the ice, the mark of being there. Polar bears are hunted for food, their carcasses are cut up on the ice, their blood is drunk by the 1872-4 expedition crew as a precaution against scurvy. In a later age the bears are tagged, for scientific research, have teeth removed, leaving trails of blood. Symbolically the blood on the ice represents the suffering and sacrifice of the explorers, and also the suffering they cause. But the blood seeps or is sliced away. There is a recognition of the transience of sacrifice, the devaluation of hard won achievements. The blood on the ice image also has an echo in the pale red wine stain found on Mazzini's white carpet in Vienna. The conjunction of blood and wine here suggests a symbolic sacrifice with religious overtones. But Mazzini's sacrifice is not called for, his journey is a wan, eviscerated simulation of that of the earlier Arctic explorers.

To elaborate: Schrecken des Eises und der Finsternis delineates a history 
of lost heroes. The Ich-Erzähler is critical of the general context of imperialistic heroicism in the Age of Exploration. Weyprecht and Payer are placed in context of an explorer history which appears to be a "Chronik des Scheiterns" (88). To title the history of the Arctic explorers as such hardly leads the reader to anticipate a chronology of distinguished, exceptional achievements, a parade of explorer-heroes. In fact those men searching for a passage through the ice to Asia, those various "Ausgewählte Vorläufer" of the Weyprecht-Payer expedition, are described as taking part in a "Totentanz" (60). Archive reports list these explorers as variously "verschwunden, gestorben, erschlagen, verschollen, umgekommen" (90).

However, the reading of texts of the historical time of exploration reveals a bold presumption and massive confidence; a time of great national egocentricity and grand gestures. In 1494 an agreement between Spain and Portugal divided up the known and unknown quarters of the globe. "Die Neue Welt und alle ihre Länder, die bereits entdeckten wie die noch unbekannten, seien aufzuteilen unter den Völkern der Iberischen Halbinsel" (51).

This lust for the new, for power and wealth led to excesses far from any altruistic impulse of exploration. The Aztecs recorded their observations of the greedy European invaders this way, "Die Kalkgesichter waren entzückt. Affen gleich wiegten sie das Gold in ihren Händen ... Wie hungrige Schweine gierten sie nach dem Gold" (52). The horrific actions of Pizarro against the Incas; "Er läßt taufen und hinrichten, zerstampft was sich widersetzt, und widmet seine Massaker dem Herrn Jesus und der spanischen Krone" reveal not only the brutal actions of the imperialising European, but in its tone the late twentieth century's critical recognition of the past age's arrogance and ignorance. There is a recognition of the hero as 'lost' not only literally in the casualty lists of expeditions but in the narratorial rejection of their actions in the context of a new reality, that of the late twentieth century. The symbolism of blood on the ice is noted here, signifying the violent grasping after new lands and victims created by such action.

Yet within the general context of a "Chronik des Scheiterns", the curricula vitae of explorers, Weyprecht and Payer, (31-5) suggest that towards the end of the nineteenth century their expedition will achieve 
what others have not. Both men had already won honour and high respect through their actions and knowledge. They appear to approach the expedition with altruistic motives, both are men of science, inspired by the dream of extending knowledge of the remotest, most extreme corners of the globe; Weyprecht, the man of measurement and objectivity, Payer, the romantic, lyrical observer and enthusiastic man of action.

Weyprecht, polar explorer and "Kommandant zu See und Eis" in 1872, had already had a distinguished career in the Austrian navy $(31,32)$ and was noted for his clever, considered actions in the "Seeschlacht von Lissa". He was widely travelled, had been to Asia, sailed to the American continent, as well as the eastern Mediterranean. He had an excellent command of Italian, Hungarian, Serbo-Croat, French, English and Norwegian. He published many articles on navigation, meteorology and oceanography and collected a swag of honours (32). He was given the sea command of the Austro-Hungarian North Pole expedition at the age of 33. Interestingly, to compare, Mazzini was 32 when he disappeared into the world of ice and darkness.

Julius Payer, "Kommandant zu Lande" was no less distinguished than Weyprecht. History records him as a first lieutenant, cartographer, alpine and polar explorer, writer and painter. His high mountain climbs included more than thirty first person ascents, and more than sixty peak climbs. He discovered the Tyrol and Franz Joseph Fjords on a six hundred kilometre march along the east coast of Greenland. He published many articles in the areas of cartography, geography and Arctic adventure. He won many honours from scientific societies, alpine clubs, won international orders and medals and had the reputation of being the best dog sled driver born outside the Polar Circle.

Defined by the expectations of the society in which these men lived, both were heroes, men of distinguished achievement and superior qualities of leadership, knowledge and endurance. They were of the elite; Enlightenment heroes, privileging the world of science and discovery, new possibilities of endeavour and knowledge in an ordered and disciplined world. They successfully returned from the Arctic Circle, having survived more than two years of deprivation and intense suffering. They had compiled scientific data in a region newly opened to the minds and bodies of the imperialistic 19th century. And they are feted heroes upon their mira- 
culous return. What qualities of heroism supported this?

Their journey through the ice and darkness was a journey that pushed them to extremes of external and internal experience. From the moment the expedition becomes imprisoned by the ice when their ship the 'Tegetthof' becomes ice-locked, the traits. of the two leaders become clearly differentiated. "Weyprecht bleibt ernst ... Nächtelang sitzt er allein in einem Beobachtungszelt ... führt seine meteorologischen, astronomischen und ozeanographischen Journale" (102). For Payer, “ ein Beobachtungszelt ist ihm zu wenig ... er will neue Länder oder Seewege entdecken ... er will in einem großen Jubel zurück kehren, mit einer wunderbaren kosmographischen Neuigkeit ..." (104). In contrast "die internationale Hetzjagd nach Entdeckerruhm und nördlichen Breitenrekorden sei (Weyprecht) zuwider" - "er kehre lieber mit gesicherten Ergebnissen und einer vollzähligen Mannschaft zurück als mit der ungefähren Skizze eines Gletscherlandes". But for Payer "ohne Erfolg, ohne Land heimzukehren sei für ihn beschämender als der Tod" (104).

Weyprecht's personal challenge in this expedition can be seen in his journal entry, "In der Erforschung der Räthsel, mit welchen sie [Natur] uns umgiebt, kommt das Streben des denkenden Menschen nach Fortschritt zum vollsten Ausdrucke" (103). His perceived role can be seen in Newton's deeds, "er gab der ganzen denkenden Menschheit einen Stoß nach vorwärts, indem er sie in ihren eigenen Augen erhob und ihr zeigte, wessen der menschliche Verstand fähig sei" (103). and Weyprecht's immediate purpose follows, "Wer die Natur wahrhaft bewundern will, der beobachte sie in ihren Extremen" (103). Weyprecht is a man of purpose, principle and controlled enthusiasm, "er berechnet... beschreibt, kalkuliert, stellt Zusammenhänge her. Alles an ihm ist Aufmerksamkeit" (102).

In Weyprecht's polar domain he sees himself as centre of his crew's world. Marola falls to his knees in prayer at the first amazing polar lights, asking the Madonna for help. "Aber Weyprecht sagt ihnen, sie sollten nicht auf Wunder vertrauen, sondern auf ihn" (101). The man of science assumes all responsibility for ordering and securing their world. He will be their saviour. Weyprecht "war die Autorität ...Tröster und Prophet ... letzte Instanz aller Fragen" (135).

The religious analogy continues as the expedition's isolation and deprivation is compared to Job's in the Land of Uz. The trials of 
depression and sickness are added to the extremes of cold and darkness. Weyprecht's religion is order, routine, rationality and discipline. "Weyprecht sagt ihnen, daß es vor allem die Ordnung sei, die sie am Leben erhielte ... das Festhalten an der Disziplin und am Gesetz sei geradezu Ausdruck der Menschlichkeit und der einzige Weg, um in der Einöde zu bestehen" (133).

Weyprecht's mantra-like, "Wir werden zurückkehren. Ich weiß es," (86) conveys a certainty consistent with the crew's perception of "unerschütterlich Weyprecht" (86), calm, considered, confident. Only once does Weyprecht's facade crack; revealing the responsibility and strain of leadership. He acts in a spontaneous and unconsidered way, running off to find his co-leader Payer when Popischill staggers back to the ship during the first sled expedition, "Weyprecht nimmt nicht einmal ein Gewehr mit. Ohne Pelz rennt er davon" (202). At all other times Weyprecht's thoughts and emotions are kept hidden. In Weyprecht's "Rückzugs Tagebuch", he wrote, "Jeder verlorene Tag ist nicht ein Nagel, sondern ein ganzes Brett an unserem Sarge ... ich mache zu allem ein gleichgültiges Gesicht aber ich sehe sehr wohl ein, daß wir verloren sind, wenn sich die Umstände nicht gänzlich ändern ..." (242). Suicide is far preferable to his expedition's possible dishonourable degeneration into chaos, cannibalism and insanity, "Nein, eine kaiserlich-königliche Nordpolexpedition konnte ... durfte nicht zugrunde gehen wie ein Rudel ausgezehrter Wölfe" (242).

The thinness of civilisation's veneer, of notions of honour and order among human beings, is to be seen not only in the altercations of minor officers and crew as their deprivation and exhaustion become severe, but also in the actions of the hero-leader Payer. Payer's anger, his emotion so overcomes his rational, civilised behaviour that he quarrels violently with his officers and threatens the life of Weyprecht should they seem unable to survive the return journey. From Weyprecht's journal, "(Payer) erklärte mir sogar unumwunden, er werde mir nach dem Leben trachten, sobald er sehe, daß er nicht nach Hause zurückkehren könne" (243).

This loss of control is not a final isolated incident. Payer is a more emotional figure than his co-leader. He lyricises the Arctic landscape ("Violette Schleier des Frostdampfes" - 108). He is enthusiastic and 
impatient to experience the world of ice, to impose first hand his existence upon it, which he does by naming whatever formation his eye falls upon. "Payer streut seine Namen wie Bannsprüche über den Archipel, forscht dabei in seinen Erinnerungen und findet immer neue Städte und Freunde, die er im Eis verewigen will..." (209). This naming reaches the ridiculous extreme of not knowing what is being named, "auch der Kommandant kann nun nicht mehr wissen, ob, was er tauft, Felsen sind oder Wolken" (220).

Yet Payer is also the man of science, recording objectively the effects of the cold on himself and his men as biological specimens. "Die Secretion des Schweißes hört gänzlich auf ... der Urin nimmt eine beinahe hochrothe Farbe an ... Eine interessante Wahrnehmung ist auch das Bleichen der Bärte unter diesen Einflüssen" (199).

Under extreme conditions Payer appears somehow superhuman. "Er leidet unter den Strapazen, unter den fünfzig Kältegraden, den Erfrierungen und dem schmerzhaften Auftauen erstarrter Glieder wie jeder andere auch - aber er wird nicht müde ... Payer zwingt seine Jäger mit ihm Felswände zu durchsteigen, wenn die anderen rasten, zeichnet und schreibt mit blaugefrorenen Fingern ... und begutachtet seine geplatzte Haut ... wie Frostschäden an einer Maschine, einer Versuchsperson, die nichts, nichts empfindet als Begeisterung" (200).

Payer pushes himself but mostly his sled crews to the extremes of suffering, "Lukinovich scheißt sich beim Ziehen an und Catarinich ist schneeblind; seine Augenhöhlen sind tränende Wunden; die Anstrengung treibt ihm das Blut aus den Poren ... Am schlimmsten leidet Popischill; er stöhnt vor Schmerzen und fürchtet, der Doktor werde ihm die erfrorenen Hände amputieren" (202).

It is Payer's actions on the sled expeditions that allow the reader to assess the effect of Payer's obsession with exploration and discovery. With the second expedition Payer "will jetzt auch noch einen neuen Breitenrekord", the eighty-second parallel. The sled party is divided when Sussich and Lukinovich cannot go on. "Herr Oberlieutenant will das Land bis an sein Ende durchmessen, er will alles sehen, er muß alles sehen, und er wird auch den zweiundachtzigsten Grad nördlicher Breite überschreiten und vielleicht auch den dreiundachtzigsten und den nächsten: Da kann er keine Hinkenden, keine Fiebernden und keine Mutlosen gebrauchen" (212). 
Payer's second order is useless, no one in either group can find their way out of the labyrinth of ice without navigator Orel.

The sled takes off once more, the dogs leave "das Blut ihrer rissigen Pfoten auf dem Eis ... ein rotes Muster, das von den Schlittenkufen zerschnitten wird. Die rote Sprenkelung, die dunklen Parallelen der Spurrinnen - die Route der Nordfahrer ist an diesen Apriltag wie eine Tapete ..." (213). The image of blood on the ice compounds with the description of the torturous pain of Klotz's feet, "seine blutenden eiternden Füße, wo einmal Zehennägel gewesen sind, ist nur rohes faulendes Fleisch" (214). Payer's response to Klotz's admission of his condition is anger. Astonishingly, Klotz is sent back to the other group alone. The almost immediate plunge of the laden sled and Zaninovich into a crevasse leaves the group further divided and in great danger. Payer cuts himself free and runs off for help, casting his clothing aside as he runs. The others soon lose him out of their sight as they struggle to keep up. Catastrophe seems imminent, initiated by Payer's actions. Haller's. misgivings, expressed to others, "Der Herr Oberleutnant hat auf einem Gletscher einen Fehler gemacht und ist dann verzweifelt gewesen" (219) are later not to be found in his more dispassionate and objective recording of the event in his journal. "Somit ist alles glücklich und ohne Schaden abgegangen. Der Herr Oberleutnant konnte wieder weiterreisen ..." (219). Through this the reader understands the .whitewashing of historical recording. Payer's actions are not consistent with those of a hero. Haller records a sober, objective version for posterity.

The image of blood on the ice, evoking the pain and suffering experienced under conditions of hardship and Payer's obsession, make clear the role played by the 'little men' in this text. The heroes of the novel do suffer but not to the extent of the crew.

On this second sled expedition, the crew again "messen und taufen und leiden. Nur Payer scheint auch diese neuerliche Tortur mit Begeisterung zu ertragen" (207). He records "es kann nur wenig Spannenderes geben, als das Entdecken neuer Länder" (208). But the narrator provides another perspective; "Aber womit immer der Kommandant auch spielt und was immer er erlebt - die Untertanen erleben es anders; Payer allein hat schließlich die Freiheit, die Zuggurten jederzeit abzustreifen ... dann allein und ohne Last über das Land zu gehen" (208).

This new perspective indicates a shift in focus in the nature of historical 
recording. Who is the hero? The hero-leader at the centre, or the unsung and largely unrecorded individuals on the periphery of the spotlight? The narrator acknowledges the experience of the 'little man' in the text. Haller's sober journal entries, the dying Krisch's "Protokoll einer Agonie", Klotz's "Versteinerung" (when his body remains with the icelocked 'Tegethoff', but his mind and spirit spend winter down south in Sankt Leonard) are the peripheral focus. By including them the narrator provides the reader with a "Chronik mehrerer einander ganz fremder Expeditionen ... Jeder berichtet aus einem anderen Eis" (41). However the hero figures are not decisively displaced. It is Weyprecht and Payer who retain our more constant focus.

The image of blood on the ice operates on several levels to figuratively represent aspects of the experience of the explorers and their expeditions in alien terrain. The blood marks the suffering of those that bear the burden of discovery, the 'little men' of the expeditions, and also those civilisations wiped out by the wave of European discovery of their worlds. But the blood on the ice seeps away, or is sliced through by the following sled blades, the suffering, or the recognition of it fades. The effort and attainment are also transient. The trauma and deprivation undergone by the 'Tegetthof' expedition after more than two years in the ice is also sloughed off by the sled runners of the response of those at the centre, the powerful circles in Vienna and new expeditions, new discoveries, the passing of time.

What we might call the 'blood intensity' of experience also fades in the nature of being recorded. Which experience is reality? Whose journals bear true witness? Do we accept the constructed reality of the Ich-Erzähler who creatively presents the possibilities of reality or accept it as one of many possible interpretations of possible scenarios?

Archival material records the reality of Weyprecht and Payer's triumphant return to Vienna. They are acclaimed heroes initially as the expedition returns from the north. The Neue Freie Presse reports on the 26th September, 1874; "Immer und immer umtoste neues Hoch und Hurrahrufen die Wagen. Der Wagen, in welchem die beiden Führer saßen, war mit mehreren großen Lorbeerkränzen behangen" (253). But the recognition and admiration are eroded away by the "Geplauder der Aristokratie ... Gerede der Militärs, ... Gerüchten am Hof oder den Kommentaren aus der Kai- 
serlichen Akademie und den Zirkeln der Geographischen Gesellschaft" (255).

Payer in particular suffers from this treatment, "er allein, Julius Payer, der Held, der nicht bloß geachtet, sondern verehrt, geliebt! sein will, ist verletzbar geblieben - und wird verletzt" (255). Comments such as "Herrn Payers Kartographierung dieses sogenannten Kaiser-Franz-Joseph-Landes sei bedauerlicherweise doch sehr, sehr ungenau", (255) destroy Payer's faith, "Sein Land eine Lüge! ... (das Land) das er unter Qualen vermessen hat?" (256). He is mocked during a lecture with the interjection, "Wenn es nur wahr wäre!" (256). Payer's later comment "Was die Entdeckung eines bisher unbekannten Landes anbelangt, so lege ich persönlich heute keinen Werth mehr darauf' (256) reveals his own vulnerability and surrender. The broken man is pitied by one of the new generation of heroes, Sven Hedin, "Es erregte mich zutiefst ... daß ein Mann der Tat wie Julius Payer ... von seinem Volk vergessen und vernachlässigt in Armut leben mußte ..." (259). The narrator records the general devaluing of the sacrifices of these heroes, "Aber wer würde zu behaupten wagen, $\mathrm{da} B$ alle Qualen und Leidenswege der Passagensucher sinnlos gewesen seien ...?" (91). Payer's realisation of himself as a lost hero comes specifically from the treatment accorded him by others. There is no self doubt revealed, arising from a consciousness of any unheroic action on the expedition. His heroism is lost when he loses the admiration and respect of others.

Weyprecht responds to the reception in Vienna in the following way; "er hört gar nicht auf das Geschwätz von Intriganten, ... will nichts mehr werden ... der sehnt sich oft ins Eis zurück" (255). The initial delirium of the expedition's triumphant return to Vienna is described through the delirium of Weyprecht's illness as he is returned to his home town to die. Weyprecht had tried to warn against the intoxication of exploration "Denn der Forschung und dem Fortschritt sei nicht mit immer neuen Opfern an Menschen und Material zu dienen ..." (251). Weyprecht had criticised the trend of arctic research, his comments on which are reported "(Sie) sei doch zu einem sinnlosen Opferspiel verkommen und erschöpfe sich gegenwärtig in der rücksichtslosen Jagd nach neuen Breitenrekorden im Interesse der nationalen Eitelkeit" (251). Weyprecht's humaneness leads him to reproach his own actions, he rejects his own heroism (he is sick 
of hearing "Geschwätze über meine Leistungen, über meine Unsterblichkeit ..."(251). He becomes a victim himself of the extremity of conditions he has earlier survived, and the conditions in which he finds himself upon his return, and dies of tuberculosis six years later.

Weyprecht is a distinguished and superior Subject in the context of his time. Yet his doubts indicate' a time of reconsidering, reevaluating. $\mathrm{He}$ shrugs off his own heroism, seeing clearly the wider scope, the transience of fame and its danger. It is the symbolic blood on the ice that leads him to contemplation of this.

By the time of Weyprecht's death, as Payer wrote his obituary of "den todten Freund und einstigen Schicksalsbruder", the devaluation of their achievements by the leaders of their society was such that, "das neue Land (war) schon nichts mehr wert" (253).

But Payer does not completely abandon dreams of glory. He leaves Vienna for a new life and a new obsession, painting. His paintings lead him back to the world of ice. They become more and more huge, "Schaufenster in eine furchtbare Welt" (257). Payer "beginnt sein eigenes Drama zu malen" (257), finally painting his "Hauptwerk", a scene from the return of his North Pole expedition. The painting is "mehr als alles eine Verherrlichung Weyprechts" (257). Refused heroic proportions for his story in real life, Payer recreates it on wall-size canvasses as the artist.

He plans an expedition of painters into the Polar Circle and as his plans become more and more grandiose and eccentric, his status as hero is to an extent revived. Other expeditions confirm his earlier findings; "Nein, der alte Mann, der jetzt über die Dörfer geht und in Pfarrsälen von Basaltküsten und Lichtwundern erzählt, der ist kein Lügner, der weiß wovon er spricht..." (258). He is still viewed with pity; it is regretted that such a man must "wie ein Händler umher[...]reisen und für wenig Geld Vorträge ... halten" (259). In the new century Payer plans crazy campaigns to conquer the North Pole by submarine, blasting his way up through the ice. In the second decade of the twentieth century the visionary suffers a stroke and dies half-blinded and unable to speak.

The acts of heroicism by both Weyprecht and Payer are ultimately inconsequential. The blood on the ice is sliced away by the sled's runners, or bleaches away into the massivity of the world of ice. Their effort and the sacrifice are transient, their mark, their impression fades. The white world of the Arctic is seen by man to be some sort of tabula rasa, to be 
written upon in terms of their conquering exploits. But the world of ice and darkness becomes an active creature who howls, creaks, raises up cliffs of ice, splits into crevasses and triumphs. The actions of so-called Arctic heroes are puny in the face of the might and power of the natural world on the periphery. Yet even in the centre, the world of science and knowledge, the measuring and observing of the Arctic world become disputed marks on maps, notes on paper. The bounty of knowledge the explorers return with is superseded by those that come after. This transience of achievement, the ultimate dissolution of what has been won, often by deprivation, suffering, even tragedy, is symbolised by the blood on the ice that seeps away. It is this transience which perhaps indicates the essence of what it is to be the lost hero in the novel.

With the end of the nineteenth century the age of the hero-leader appears over. The twentieth century ushers in a new world with a world view paradigm shift from certainty to doubt, from grand gestures to a recognition of a general and pervasive transience, a changing perception both Weyprecht and Payer have experienced first hand. The later experiences of Weyprecht and Payer come to symbolically parallel that of the Austro-Hungarian Empire itself. Their North Pole expedition takes place on the virtual cusp of two ages. Weyprecht and Payer experience the transience, and finally the collapse and disintegration, suffered by the Empire. Weyprecht suffers physical collapse and death, Payer experiences the disintegration of his social place and his mental state, his eye sight and his speech before his death in the second year of the First World War. The image of blood on the ice is one which highlights the connections drawn between Mazzini and those experiences of the earlier expedition. Mazzini seeks to emulate those heroes of an earlier age, to make a journey of the imagination assume the hard edges of reality. His heroism, his journey, however is a pale imitation of the journey undertaken a century earlier. The blood on the ice image first found in Mazzini's world is, as mentioned, the faded, red wine stain the narrator notices on the white carpet in Mazzini's flat which Anna Koreth is clearing out after Mazzini's disappearance. The sight of the stain leads the narrator to recall an experience recorded in Mazzini's journal, the tagging of a polar bear. A tooth is torn out of the bear's jaw, and blood oozes onto the ice. Mazzini is also symbolically 'tagged' by this image. The juxtaposition 
of the two images highlights another variation of the hero as 'lost' in the text. It centres on the notion of authenticity.

The writer of the preface "Vor Allem" indicates right from the beginning it is the process, the journey, the authenticity of first hand experience that has been lost when we consider the experience of the hero in the late twentieth century. We have lost the ability to be heroic. "Was ist bloß aus unseren Abenteuren geworden ...?" We have created the illusion by reporting, recording and publicising "daß selbst das Entlegenste und Entfernteste zugänglich sei wie ein Vergnügungsgelände" (9), that the world is somehow smaller, adventure is now a matter of consulting bank balances and plane time tables. Ironically in the act of reading the reader also is part of this mediated experience, is only vicariously participating in Mazzini's adventure.

The story of Mazzini is narrated parallel to the unfolding of the experiences of the Weyprecht-Payer Expedition. The Ich-Erzähler reports Mazzini's intention as expressed at Anna Koreth's literary soiree. In the adventure stories he writes, Mazzini says, "er entwerfe gewissermaßen die Vergangenheit neu" (20). At this "Abendgesellschaft" it is rather condescendingly pointed out that "eine phantasierte Geschichte" such as Mazzini specialises in, "die tatsächlich schon einmal geschehen sei, würde sich doch durch nichts mehr von einer bloßen Nacherzählung unterscheiden" (21).

This observation is the crux of Mazzini's dilemma in the late twentieth century. What he fantasises about, what adventures he dreams up have been done before. He is caught in some Nietzschean treadmill of eternal recurrence where the simulation of what once was, denies him his own sweet blast of authenticity. Mazzini initially stands by his cerebral adventuring, he privileges the imagination, the creative act of writing. $\mathrm{He}$ rejects the notion of his adventures as "rein[e] Tatsachenbericht[e] ihm genüge schon der private, insgeheime' Beweis, die Erfindung der Wirklichkeit geschafft zu haben" (21). In his stories, Mazzini is the outsider who reports, the eye witness who records; "[er] berichtete als Augenzeuge von Flüchtlingkarawanen und Kämpfen im Irgendwo" (21). The hero of the late twentieth century is displaced from the spotlight of his adventure. He strives through imaginative recreation to find the authenticity of an earlier age. 
The world of the imagination and story telling were central to Mazzini's childhood in Triest. His immediate world of his mother's Scarpa relatives were explorers and heroes at least in Lucia's mind. “...am Küchentisch ... war die Vergangenheit übermächtig und malerisch ... Antonio, der Urgroßonkel, Antonio Scarpa ... sei ... bis an den Nordpol gesegelt..."! (17). The Italian hero Umberto Nobile was Mazzini's mother's favourite. Mazzini was enthralled by the world of ice and heroes, "Was war das für ein Meer, auf dem sich Helden in Lumpengestalten, Kapitäne in Menschenfresser und Luftschiffe in eisige Fetzen verwandelten?" (18).

Later in Vienna, Mazzini discovers Julius Ritter von Payer's report on the Austro-Hungarian North Pole Expedition in Anna Koreth's book shop and as if the report were a confirmation, "(ein) Beweis für eines seiner erfundenen Abenteuer ... rannte [er] einer verjährten Wirklichkeit nach".

This time Mazzini found the world of archives too limiting. He abandoned an imagined, fantasised mediated reality, the world of his stories and reached for the authentic experience. He plans his journey north, "Mazzini reiste ins Eismeer. Mazzini zelebrierte die Chronik der Payer-Weyprecht expedition vor den Kulissen der Wirklichkeit ... Mazzini wanderte über die Gletscher" (23-4).

The would-be hero had found his quest, to follow in the footsteps of Weyprecht and Payer. He takes up the challenge of the preface "Vor Allem" and becomes once more a "Fußgänger und Läufer' (9). He abandons the recording, reporting and mediating; the "Ansichtskarten ... illustrierten Reportagen und Berichte" (9). In his journal, later returned to Anna Koreth after Mazzini's disappearance, he had written, "Wohin wir selbst nicht kommen, schicken wir unsere Stellvertreter, Berichterstatter, die uns dann erzählen, wie's war. Aber so war es meistens nicht ... uns bewegt ja doch nichts mehr ... uns unterhält man" (22). Mazzini now wants to find out for himself. Mazzini writes no more stories and finally even stops writing in his private journal in Longyearbyen. He progressively leaves behind the transport and technology, the twentieth century itself, his own identity within it, and disappears into the ice.

Mazzini is literally the lost hero. He is physically absent from the contemporary action of the text. He disappears apparently while driving a dogsled team in the Arctic landscape outside Longyearbyen. As a 
traveller, Mazzini "reiste oft allein und viel zu Fuß. Im Gehen wurde ihm die Welt nicht kleiner, sondern immer größer, so groß, daß er schließlich in ihr verschwand" (11).

Clearly, from an early age Mazzini is drawn to heroes and acts of heroism. The text, Payer's report of the 1872 expedition to the North Pole fires Mazzini's imagination to reinvent reality, but his own act of writing is finally rejected. Mazzini's intention is re-contact authentic experience. Ironically he attempts that by following in the footsteps of others.

In several other ways also, it appears Mazzini is anti-heroic. The intention to be heroic in itself is not enough. Who is Mazzini? He is an outsider, a traveller. He is neither Italian nor Austrian. He acts out the "Fluchtphantasien" of his father by leaving Triest for Vienna. There he stood out as different in Anna Koreth's literary group. "Mazzini ... war eine Ausnahme. Er sprach viel von sich ... in einem höflichen Deutsch, dem man anmerkte, daß es aus der Emigration kam". He was "seltsam und kauzig" (20). However Anna Koreth took him under her wing, introducing him as her Josef. Mazzini appeared to have little meaningful contact with others. Even with Anna Koreth, they would speak the whole evening, "Aber dann können sie einander nicht mehr zuhören, und doch reden sie einen Abend lang weiter; jeder aus ëinem anderen Eis" (47).

Mazzini looked as though he needed protection, "ein kleingewachsener, fast zierlicher Mann" (24). Preparing for his journey north he was seen as a naive, uninformed tourist.. Governor Thorsen of Longyearbyen replied to Mazzini's letter, "Ich habe doch Zweifel, ob Sie über die Bedingungen der norwegischen Arktis ausreichend informiert sind" (64).

The narrator conjectures that Mazzini was more swept along than decisive in the planning stages of his trip, "Es schien als ob die Dinge tatsächlich ihren Lauf genommen und Mazzini diesen Lauf erst nachträglich als seine Entscheidung auszugeben versucht hätte" (64). But Mazzini packs his down clothing, his sleeping bag and climbs aboard the Scandinavian Airlines flight to find his reality.

In Oslo Mazzini is welcome only on sufferance as Kjetil Fyrand's "Schützling". Fagerlien, head of the "Polarinstitut", is unimpressed with Mazzini who has claimed to be writing a book on the 1872 North Pole expedition simply to get onto a research ship heading into the Polar Circle. "Fagerlien kannte zu viele arktische Chroniken ... [er] hatte seine 
eigenen Helden" (72). The underlying antagonism between the two surfaces with Mazzini's quiet comment in Italian, "Ich bin nicht Nobile".

Mazzini is seen as an intruder, a possible danger. He rejects this in his rejection of any identification with the dishonoured Italian hero, Nobile, who had let himself be rescued before his men and the search for whom had cost the lives of many, including that of the explorer Roald Amundsen. Mazzini states his identity clearly. But the question of identity is at issue. Mazzini is sarcastically referred to as "Weyprecht" by Malcolm Flaherty in Longyearbyen. He is given Cape Payer in a sardonic gesture by Fyrand, his inheritance so to speak. At one point Mazzini does introduce himself as Antonio Scarpa, sailor, his great uncle. The notion of the hero seems for Mazzini a question of personal identity, obviously one which is in flux in the course of his journey in the North.

Mazzini's relative insignificance in a social context is reinforced by the references to him as "der Junge aus Wien, Fyrand's "Schützling", (175-6) "der Kleine", "das Ferienkind (121). He is judged as unmanly, "der Junge aus Wien scheint nicht eben viel zu ertragen." He is seen as a "besoffener Tourist" (96). Later, in his polar outfit, Mazzini appears "ein schmächtiger Faschingsnarr" in his "Gletscherbrille", his nose smeared with "Frostsalbe" (74).

In Longyearbyen Mazzini's oddness does not stand out. Characters such as Fyrand and the eccentric Flaherty are the hero-figures of this community on the periphery. Indeed, Fyrand with his dog sled team carries "das untrügliche Zeichen einer arktischen Männlichkeit" (129). Mazzini believes himself to be a part of this community, but he is still seen as "ein Journalist, Schriftsteller oder so ähnlich, der sich in die Polargeschichte vernarrt hat" (126). In fact "man hätte den kleinen Italiener ohne weiteres übergehen und wieder vergessen können, wenn er ... nicht immer wieder an der Seite von Fyrand ... Flaherty ... aufgetaucht wäre" (126).

Mazzini's voyage on the research vessel the 'Cradle', is also a failure considering his intentions. The awaited confrontation with the ice is anticlimactic. The Cradle " schiebt kleinere Schollen beiseite, reitet auf große Flarden mit unvermindeter Geschwindigkeit auf ... bricht dann donnernd ein ... so geht man im Jahr 1981 mit dem Eismeer um" (156). Mazzini's experience of the world of ice is shown symbolically as he observes his 
reflection in the glassed wall map of the Arctic. "Quer über sein Gesicht verläuft die weiß gezackte Linie der sommerlichen Treibeisgrenze, an seinen Schultern trägt er Landzungen und Inseln" (157). Mapped, measured and enclosed, Mazzini is shut off from the authenticity of the Arctic. And then comes the failure of Mazzini to see Franz Joseph Land which his heroes had discovered a century before. "Wir kehren um. Wir kommen nicht durch. Du wirst dein Franz-Joseph-Land nicht zu Gesicht bekommen" (176). After this Mazzini leaves his post at the ship's railing and returns to the world of books and writing, "ein Sekretär der Erinnerung" (177).

The cumulative effect of these experiences of anticlimax and failure is found in Mazzini's not just remembering, but reliving the story of Umberto Nobile, triggered by the sighting of the memorial to Amundsen and Nobile at Ny Aleson. The dishonoured hero, who "verletzte nach ihrem Schiffbruch jenen Ehrenkodex, der den Ablauf von Untergängen regelt. Und das verzieh ihm die Welt nicht" (160). Mazzini has already indicated he will not be mistaken for a dishonoured hero. On the ship's return to Spitzbergen Mazzini takes as his motto the fatalistic "Was geschehen soll, geschieht" lifted from the film "The Barefoot Contessa", an interesting reflection on the impotence he himself was feeling so to adopt the "Wappenspruch" of the impotent Count. On the return voyage Mazzini sits "Wie einer, der sich auf seine Entlassung, auf die große Freiheit vorbereitet" (176-7).

There is only conjecture to the further events leading to Mazzini's disappearance. He stops writing in his journal on reaching Longyearbyen. The narrator philosophises "Wer seinen Ort gefunden hat, der führt keine Reisetagebücher mehr" (228). Mazzini makes no plans to leave as the Arctic winter approaches. He has not abandoned his quest. Like Payer, Kommandant zu Lande, Mazzini wants to cover the snow and ice by dog sled. At first frozen with fear, then later with perseverance Mazzini learns how to handle the team. But when Fyrand returns from a conference in Oslo, he finds Mazzini's room "aufgeräumt und leer. Die Hunde fehlten auch" (234). Weeks later two sled dogs return in a vicious crazed condition, still caught in the remains of their harness. No sign of Mazzini is found.

Mazzini left Vienna to relive the 'blood on the ice' intensity of the 
Weyprecht-Payer expedition. Mazzini's pretensions were heroic, but his journey was of the 'little man', the decentred individual whose exploits are cerebral. His would-be attainments are copies. His identity and reality was formed by the texts of the past. He has no identity outside of his stories and his obsession with Weyprecht and Payer. He shakily treads a path to the periphery hoping to find his place, but there finds another periphery beyond. He simply disappears. In the postmodern age the concept of the hero is lost. Not just the superior Subject, or the doubting, introverted hero, but the notion of Subject itself, the hero, is 'dead'. Mazzini's fate is indicated by the image of the faded red wine stain on the white carpet in his Vienna flat. He seeks the authenticity of adventure, of heroic action. He is prepared for sacrifice. But his impotence is revealed. He fails and does not even leave a "Rest" for his would-be rescuers to find. While the wine stain symbolises blood it is never more than a bleached out representation, not the real thing. Irony undercuts the expectations associated with the religious connotations of the image. The reader is left uncertain, as is the narrator. Is Mazzini's disappearance the final failure, or an voluntary acknowledgement that he has no place, the hero is lost?

The reader also responds to the hero as 'lost' in terms of narrative technique used in the novel. The heroes' experiences are perspectivebased, and become more remote the more they are mediated by the creative conjecture of the Ich-Erzähler. The various text types which create the patchwork of narration, the various perspectives provided by journals, log books, pamphlets, newspaper reports, excerpts, column listings are presented, linked, commented upon by the Ich-Erzähler. There is the assumption the reader will query the 'truth' of the texts used; the archival material is authentic, Mazzini's journal can supposedly be found as an extant text somewhere in Vienna, but then there is the conjecture and creative linking of the narrator's text. There is an observed dialectic tension between notions of authenticity and mediation in the text, before which the narrator appears helpless: finally he is "allein mit allen Möglichkeiten einer Geschichte, ein Chronist, dem der Trost des Endes fehlt" (263).

The narrator's assumption of Mazzini's quest; the reinventing of the reality of the Weyprecht-Payer expedition and the manner of his assuming authorship of Mazzini's journey both lead to a perception by the reader of 
the hero being 'lost'. Not only are experiences mediated by the organisation of texts but Mazzini recedes from the reader's focus as the telling of his story is seen to be at the whim of the narrator, who plays with possibilities.

The Ich-Erzähler of the novel indeed plays a variety of roles in the novel. He predominantly shadows the action, is neutral in the didactic illustration of polar and exploration history. As philosopher and chorus he is more active, he intrudes to shape our perception of the action, to interpret the events and moods. As actor he enters the scene of the action in Anna Koreth's flat, a member of the literary set and at the conclusion of the novel he sits at his writing desk surrounded by the artefacts of his narration. As director, he conjectures, chooses, assembles, patterns his texts and creates his own from them.

In these roles, the narrator simultaneously draws the reader into a sense of the authenticity of the two jaurneys while reminding the reader of the final artificiality of his text. He is quite forthright in speaking of details as conjectures, possibilities, interpretations.

The strongest actions of the narrator are found in his response to Mazzini. He feels antagonistic towards the young Italian. "Nein, ich habe nicht zu seinen Freunden gehört. Ich habe für diesen ... Mann ... manchmal sogar jene besondere Feindseligkeit empfunden, mit der man vielleicht nur jemandem gegenübertritt, der einem allzu nahe, allzu ähnlich ist" (24). He is writing to lay Mazzini and his story to rest but begins to identify too closely, "Ich bin ohne es zu wollen, in sein Leben hineingeraten" (24).

The narrator consciously assumes authorship by naming the chapters in Mazzini's journal by titling the text Der Große Nagel. "Es ist nicht Josef Mazzini's Handschrift. Das habe ich geschrieben. Ich. Ich habe auch die anderen Hefte Mazzinis mit Namen versehen. ... ich habe sie getauft" (177). Just like an explorer, imposing his existence on the landscape by naming, just like Payer, the narrator imposes his presence on the landscape of Mazzinis text.

He imposes his presence on the text also in his visualising of certain events, for example Weyprecht's speech to the sailors, "Ich habe lang an der Vorstellung festgehalten ...."; the sailing of the ship the "Admiral Tegetthof', "Ich stelle mir das schwarze Wasser eines Sundes vor" (46); and when Mazzini prepares himself for the journey northward, "dann sehe 


\section{ich Josef Mazzini" (46).}

He states his impressions, "Mazzinis Abreise erscheint mir dann als ein Hinüberwechseln aus der Wirklichkeit in die Wahrscheinlichkeit" and uses digressions to comment on topics such as the anonymity of the ordinary heroes, "Auch die Tranjäger machten Entdeckungen" (88). He defines his intentions, "Mein Bericht ist immer auch ein Gerichthalten über das Vergangene, ein Abwägen, ein Gewichten, ein Vermuten und Spielen mit den Möglichkeiten der Wirklichkeiten" (217).

The narrator is finally surrounded by the artefacts of the journey, the reality of the North Pole expedition and the Arctic, with the maps and texts, but cannot end Mazzini's story, "Ich werde nichts beenden und nichts werde ich aus der Welt schaffen" (261). He is left with all manner of possibilities, just as Mazzini was, in leaving reality for possibility in his journey north. He looks for some sign of Mazzini's fate, "Vielleicht liegt dort ein Rest für mich bereit" (262), some certainty of resolution, but finds none.

This dilemma of the narrator removes the focus further away from Mazzini and his story. The reader understands that what he/she has read is purely conjecture, a creative refashioning of texts and a creative interpretation of the issues involved. We are faced with the blend of myth and reality, historical fact stirred with possibilities and fantasy. Our focus is switched from 1872 to 1874 , to Mazzini, to the narrator, back and forth. In this interaction of texts/ realities the notion of the hero is more than ever lost.

The image of the blood on the ice in Schrecken des Eises und der Finsternis illustrates in symbolic form the text's preoccupation with notions of transience and authenticity. The central characters of both narrative strands are seen as variations of the lost hero, lost in varying degrees, to themselves, their audience and to the reader; the doubting Weyprecht, the devalued Payer, and the displaced, anti-heroic Mazzini. The narrator tries to locate himself as meaningful in his construction of the text but is left, as is the reader, with only questioning and uncertainty. 